\title{
Travel advice for the immunocompromised traveler: prophylaxis, vaccination, and other preventive measures [Corrigendum]
}

\author{
Patel RR, Liang SY, Koolwal P, Kuhlmann FM. Therapeutics \\ and Clinical Risk Management. 2015;11:217-228.
}

On page 224, Meningococcal vaccine heading, second sentence "Vaccination is recommended with the quadrivalent polysaccharide (Menactra ${ }^{\mathrm{TM}}$ )" should have read "Vaccination with the quadrivalent meningococcal conjugate vaccine (MCV4) is recommended".

\section{Publish your work in this journal}

Therapeutics and Clinical Risk Management is an international, peerreviewed journal of clinical therapeutics and risk management, focusing on concise rapid reporting of clinical studies in all therapeutic areas outcomes, safety, and programs for the effective, safe, and sustained use of medicines. This journal is indexed on PubMed Central, CAS,
EMBase, Scopus and the Elsevier Bibliographic databases. The manuscript management system is completely online and includes a very quick and fair peer-review system, which is all easy to use. Visit $\mathrm{http}: / / \mathrm{www}$.dovepress.com/testimonials.php to read real quotes from published authors. 